Publiser
Jaurnal of
Mangaduate Program Universitas Galuh
Masteview of Manajemen Studies Program
O2017

\title{
PENGARUH LINGKUNGAN KERJA FISIK DAN NON FISIK TERHADAP KINERJA PEGAWAI PADA SEKRETARIAT DAERAH KABUPATEN PANGANDARAN
}

\author{
Fitria Noorainy ${ }^{1}$ \\ ${ }^{1}$ Master of Management Studies Program, Graduate Program Universitas Galuh Ciamis \\ e-mail: fitrianoorainy@yahoo.com
}

\author{
Article History : \\ Recieved 20 April 2017 \\ Recieved in revished form \\ 21 April 2017 \\ Acepted 5 May 2017 \\ Available offline 10 May 2017 \\ Available online 10 May 2017
}

Language Transcript :

Indonesia

Key Words :

Lingkungan Kerja Fisik

Lingkungan Kerja Non Fisik

Kinerja Pegawai

\begin{abstract}
Penelitian ini diarahkan untuk diperoleh yaitu untuk untuk memahami, mengetahui dan menganalisis; 1. pengaruh lingkungan kerja fisik terhadap kinerja pegawai pada Sekretariat Daerah Kabupaten Pangandaran; 2. pengaruh lingkungan kerja non fisik terhadap kinerja pegawai pada pada Sekretariat Daerah Kabupaten Pangandaran; dan 3. pengaruh lingkungan kerja fisik dan non fisik terhadap kinerja pegawai pada Sekretariat Daerah Kabupaten Pangandaran. Metode penelitian yang digunakan adalah metode deskriptif yang dikaji dengan cara pendekatan kuantitatif, dengan alat pengumpulan data yaitu observasi, angket dan wawancara. Teknik analisis data dengan menggunakan uji validitas, realibilitas, koefisien korelasi product moment, uji hipotesis (uji signifikansi/uji t), dan koefisien determinasi. Hasil penelitian menunjukan bahwa kinerja pegawai pada umumnya sangat tinggi, hal tersebut disebabkan adanya pengaruh dari lingkungan kerja fisik dan lingkungan kerja non fisik, dan masuk pada kategori sangat tinggi. Dengan demikian ada pengaruh yang positif dan signifikan dari lingkungan kerja fisik dan lingkungan kerja non fisik terhadap kinerja pegawai pada sekretariat Daerah Kabupaten Pangandaran, namun tidak dapat dipungkiri bahwa dalam pelaksanaannya terdapat beberapa indikator yang dianggap masih kurang maksimal yaitu mengenai pegawai menjelaskan tahapan-tahapan program sesuai dengan petunjuk pelaksanaan.
\end{abstract}

\section{PENDAHULUAN}

Organisasi merupakan suatu sistem, yaitu rangkaian dan hubungan antar bagian komponen yang bekerja sama secara keseluruhan. Dimana setiap komponen merupakan sub sistem yang memiliki kekayaan sistem bagi dirinya. Terdapat hubungan yang erat antara kinerja perseorangan dengan kinerja organisasi. Dengan kata lain bila kinerja karyawan baik maka kemungkinan besar kinerja organisasi juga baik. Oleh karena itu organisasi harus benar-benar memperhatikan faktor sumber daya manusianya.

Hal yang penting dalam pengelolaan sumber daya manusia adalah mengenai kinerja pegawai. Kinerja pegawai menurut Mangkunegara (2003:11) adalah: "Hasil kerja secara kualitas dan kuantitas yang dapat dicapai oleh seorang karyawan dalam melaksanakan tugas sesuai dengan tanggung jawab yang diberikan kepadanya. Agar kinerja karyawan selalu konsisten maka setidak-tidaknya organisasi selalu memperhatikan lingkungan kerja sehingga tujuan organisasi dapat tercapai.

Tujuan organisasi yang telah ditetapkan adalah suatu kondisi yang telah disepakati oleh semua anggota organisasi. Dengan demikian tujuan organisasi dapat dicapai jika semua anggota organisasi yang mempunyai kesediaan untuk bekerjasama dan kegiatan mereka dapat dikoordinir dengan baik, selain itu pegawai dimotivasi dan diberi suatu kesadaran untuk mematuhi peraturan sehingga akan tercipta hasil kerja yang baik selain itu diperlukan adanya suatu lingkungan kerja yang kondusif. 
Apabila ternyata dalam pelaksanaannya motivasi kerja pegawainya masih rendah serta lingkungan kerja yang tida baik dan kondusif, maka tujuan organisasi akan gagal dan secara langsung maupun tidak langsung akan berdampak negatif terhadap kinerja dalam suatu organisasi termasuk di lingkungan organisasi Sekretariat Daerah (Setda) Kabupaten Pangandaran.

Sejalan dengan hal di atas maka tidak dapat dipungkiri bahwa dalam pelaksanaannya kinerja pegawai pada Sekretariat Daerah Kabupaten Pangandaran masih terdapat kesenjangan, keadaan tersebut dapat terlihat dari indikator-indikator yang penulis temukan dari Daftar Penilaian Pelaksanaan Pekerjaan.

Dalam Penilaian Pelaksanaan Pekerjaan (DP3), unsur penilaian yakni kesetiaan memiliki persentase yang paling tinggi yakni sebesar $91 \%$. Untuk kategori prestasi kerja dari tahun ke tahun hanya sebesar $79 \%$, tanggung jawab memiliki persentase yang beragam sebesar $76 \%-78 \%$, tingkat ketaatan sebesar $79 \%$, untuk nilai kejujuran dari tahun 2013-2015 tidak mengalami kenaikan yang signifikan dan hanya bertahan pada nilai $79 \%$ begitupun dengan nilai kerjasama yang memiliki nilai $77 \%$ dari tahun 2013-2015, selanjutnya untuk penilaian prakarsa dari tahun 2014 menuju tahun 2015 mengalami selisih penurunan sebesar $1 \%$ menjadi $78 \%$ dari nilai sebesar $79 \%$ di tahun 2013. Penilaian terakhir adalah kepemimpinan yang mengalami penurunan di tahun 2014 menjadi 79\% dan meningkat kembai di tahun 2015 menjadi $80 \%$.

Timbulnya masalah-masalah tersebut diduga disebabkan karena kurang baik dan kondusifnyanya lingkungan kerja, hal di atas dapat dilihat dari indikator-indikator sebagai berikut:

1) Ada beberapa diantara pegawai yang kurang taat terhadap aturan waktu, misalnya dengan tidak hadir tepat waktu sesuai jam kerja bahkan meninggalkan pekerjaan sebelum jam kerja berakhir.

2) Ada beberapa diantara pegawai yang tidak taat terhadap peraturan organisasi atau instansi terkait khususnya setda Kabupaten Pangandaran misalnya dengan tidak melaksanakan semua aturan jabatan yang ditetapkan atau juga tidak mengerjakan tugas yang diperintahkan atasan pada bidang yang ditempati.

Dari uraian di atas dapat disimpulkan bahwa untuk mencapai kinerja menjadi lebih baik maka diperlukan adanya lingkungan kerja baik fisik maupun non fisik yang kondusif. Lebih jelasnya pimpinan yang membuat suatu lingkungan kerja yang kondusif maka akan memberikan pengaruh yang besar pada peningkatan kinerja pegawai sehingga akan menunjang tercapainya tujuan organisasi. Melalui lingkungan kerja maka seluruh kegiatan organisasi Sekretariat Daerah Kabupaten Pangandaran dapat diatur, diselenggarakan dan dibina agar kegiatan tiap individu dalam struktur organisasi yang ada dapat tercapai secara optimal khususnya dalam hal tercapainya kinerja secara maksimal.

\section{METODOLOGI}

Penelitian ini dipilih menggunakan metode deskriptif yang dikaji dengan cara pendekatan kuantitatif, sebagaimana pendapat Sugiyono (2010:11) bahwa: Penelitian deskriptif adalah penelitian yang dilakukan untuk mengetahui nilai variabel mandiri, baik satu variabel atau lebih (independen) tanpa membuat perbandingan atau menghubungkan antara variabel yang satu dengan variabel yang lain".

Disain yang digunakan dalam penelitian ini menggunakan 2 (dua) disain yaitu disain deskriptif dan disain korelasional. Untuk menjawab pertanyaan penelitian pertama, kedua dan ketiga digunakan desain deskriptif sedangkan untuk menjawab pertanyaan keempat digunakan desain korelasional, dengan melihat pengaruh variabel variabel (X1) yaitu lingkungan kerja fisik, variabel (X2) lingkungan kerja non fisik terhadap variabel (Y) yaitu kinerja pegawai.

Data yang digunakan dalam penelitian ini bersumber dari pegawai Sekretariat Daerah Kabupaten Pangandaran. Selanjutnya mengenai sumber data yang akan dipakai dalam penelitian ini adalah data primer dan data sekunder. Mengenai data primer, maka penulis akan mengambil data secara 
langsung dari arsip-arsip yang berkaitan dengan Sekretariat Daerah Kabupaten Pangandaran, sedangkan untuk data sekunder (penunjang lainnya) akan dicari dari sumber lain yang berhubungan erat dengan permasalahan yang diteliti.

Alat pengumpulan datanya adalah sebagai berikut : a. Observasi, dan b. Angket. Selanjutnya mengenai teknik pengolahan data maka data hasil penelitian dan angket belum bisa dihitung secara statistik harus karena melalui proses pengujian validitas dan reliabilitas instrumen, selanjutnya normalitas data juga harus memenuhi prasyarat untuk dapat dihitung secara statistik (kuantitatif) sehingga dapat digunakan untuk menguji hipotesis. Adapun langkah-langkah yang untuk pengujian hipotesis dalam penelitian ini dilakukan langkah sebagai berikut:

- Menentukan koefesien korelasi dengan perumusan person correlation

- Menentukan besarnya pengaruh antar variabel, dengan mengunakan perumusan $r^{2} \times 100 \%$, dimana $r$ adalah koefesien korelasi yang diperoleh.

- Menentukan persamaan regresi yang digunakan, $\mathrm{Y}=a+b X$ dan peneliti menggunakan Uji regresi linier dengan software SPSS for Windows Versi. 18

.Pengujian penerimaan terhadap hipotesis penelitian, dengan pengujian jika $t_{\text {hitung }}>t_{\text {tabel }}$, maka hipotesis signifikan atau diterima dan jika $t_{\text {hitung }}<t_{\text {tabel }}$. Disamping itu untuk pengujian yang parsial digunakan ketentuan jika $F_{\text {hitung }}>F_{\text {tabel }}$, maka hipotesis signifikan atau diterima dan jika $\mathrm{F}_{\text {hitung }}<$ $\mathrm{F}_{\text {tabel }}$, maka hipotesis tidak signifikan atau ditolak. Langkah pengujian Hipotesis tersebut menggunakan fasilitas pogram SPSS for Windows Versi 18.0.

\section{HASIL PENELITIAN}

\subsection{Deskripsi Hasil Penelitian Tentang Lingkungan Kerja Fisik (X1)}

Berdasarkan hasil jawaban responden melalui penyebaran angket terhadap 74 orang responden, maka peneliti akan menguraikan hasil penelitian per item indikator tentang lingkungan kerja fisik, berikut ini:
- Semua keadaan berbentuk fisik yang terdapat disekitar tempat kerja yang dapat mempengaruhi pegawai secara langsung misalnya secara langsung berpengaruh terhadap penyelesaian tugas-tugas. Mengenai indikator ini diketahui bahwa responden yang menjawab sangat setuju sebanyak 60 orang $(81,08 \%)$, dan sebanyak 14 orang $(18,92 \%)$ menjawab setuju.

- Semua keadaan berbentuk fisik yang terdapat disekitar tempat kerja yang dapat mempengaruhi pegawai secara tidak langsung, misalnya secara tidak langsung berpengaruh terhadap peningkatan disiplin, prestasi kerja maupun kepuasan kerja. Mengenai indikator ini diketahui bahwa responden yang menjawab sangat setuju sebanyak 20 orang $(27,03 \%)$, dan sebanyak 54 orang $(72,97 \%)$ menjawab setuju.

- Kinerja pegawai dipengaruhi oleh lingkungan kerja yang langsung berhubungan dengan pegawai seperti pusat kerja, kursi, meja, dan sebagainya. Mengenai indikator ini diketahui bahwa responden yang menjawab sangat setuju sebanyak 30 orang $(40,54 \%)$, sebanyak 10 orang $(13,51 \%)$ menjawab setuju, dan 34 orang $(45,95 \%)$ menjawab kurang setuju.

- Lingkungan kerja dipengaruhi oleh kondisi gedung kantor yang baik misalnya temparatur, kelembaban, sirkulasi udara, pencahayaan, kebisingan, getaran mekanik, bau tidak sedap, warna dan lain-lain. Mengenai indikator ini diketahui bahwa responden yang menjawab sangat setuju sebanyak 20 orang $(27,03 \%)$, sebanyak 6 orang $(8,11 \%)$ menjawab setuju, dan 48 orang $(64,86 \%)$ menjawab kurang setuju.

- Memperkecil penguruh lingkungan fisik, misalnya meredam kebisingan disekitar tempat kerja baik dari luar kantor maupun dari dalam kantor itu sendiri dapat meningkatkan kinerja. Mengenai indikator ini diketahui bahwa responden yang menjawab sangat setuju sebanyak 41 orang $(55,41 \%)$, sebanyak 6 orang $(8,11 \%)$ menjawab setuju, dan 27 orang $(36,49 \%)$ menjawab kurang setuju. 
- Mengenal fisik dan tingkah laku masingmasing sehingga bisa dijadikan sebagai dasar untuk meningkatkan kualitas kerja. Mengenai indikator ini diketahui bahwa responden yang menjawab sangat setuju sebanyak 60 orang $(81,08 \%)$, dan sebanyak 14 orang $(18,92 \%)$ menjawab setuju.

- Kualitas kerja dipengaruhi oleh peralatan kerja yang baik dan memadai seperti adanya laptop, printer maupun faximile. Mengenai indikator ini diketahui bahwa responden yang menjawab sangat setuju sebanyak 20 orang $(27,03 \%)$, dan sebanyak 54 orang $(72,97 \%)$ menjawab setuju.

- Kinerja dipengaruhi oleh tempat kerja yang mudah dijangkau. Mengenai indikator ini diketahui bahwa responden yang menjawab sangat setuju sebanyak 41 orang $(55,41 \%)$, sebanyak 6 orang $(8,11 \%)$ menjawab setuju, dan 27 orang $(36,49 \%)$ menjawab kurang setuju.

- Kualitas kerja dipengaruhi oleh fasilitas kerja yang lengkap seperti dukungan teknologi informasi berupa internet. Mengenai indikator ini diketahui bahwa responden yang menjawab sangat setuju sebanyak 20 orang $(27,03 \%)$, sebanyak 6 orang $(8,11 \%)$ menjawab setuju, dan 48 orang $(64,86 \%)$ menjawab kurang setuju.

- Dibuatnya suatu petunjuk teknis dan petunjuk pelaksana yang lengkap akan membantu pegawai lebih paham mengenai bidang tugasnya masingmasing. Mengenai indikator ini diketahui bahwa responden yang menjawab sangat setuju sebanyak 30 orang $(40,54 \%)$, sebanyak 10 orang $(13,51 \%)$ menjawab setuju, dan 34 orang $(45,95 \%)$ menjawab kurang setuju.

Berdasarkan rekapitulasi hasil jawaban responden untuk lingkungan kerja fisik diketahui bahwa diperoleh skor kenyataan sebesar 3.322 yang diperoleh dari perhitungan berikut ini:

$$
\mathrm{x}=\frac{3.322}{10}=332,2
$$

Kemudian jika dipersentasekan adalah sebagai berikut:

$$
\begin{aligned}
\frac{\text { skor rata }- \text { rata }}{\text { skor ideal }} & \times 100 \% \\
& =\frac{332,2}{370} \times 100 \% \\
& =89,78 \%
\end{aligned}
$$

Dengan demikian rata-rata skor untuk lingkungan kerja fisik sebesar 332,2 yang berada pada posisi tinggi. Apabila ditunjukkan dalam persentase diperoleh angka sebesar $89,78 \%$, yang berada pada posisi sangat tinggi. Perolehan skor tertinggi diperoleh sebesar 364 yaitu salah satunya mengenai indikator mengenal fisik dan tingkah laku masing-masing sehingga bisa dijadikan sebagai dasar untuk meningkatkan kualitas kerja, sedangkan skor terendah yang diperoleh adalah sebesar 298, salah satunya mengenai indikator memperkecil pengaruh lingkungan fisik, misalnya meredam kebisingan disekitar tempat kerja baik dari luar kantor maupun dari dalam kantor itu sendiri dapat meningkatkan kinerja.

Berdasarkan hasil observasi variabel lingkungan kerja fisik sudah menyesuaikan dengan ketentuan yang berlaku, hal itu dapat dibuktikan salah satunya yaitu pegawai mengenal fisik dan tingkah laku masing-masing sehingga bisa dijadikan sebagai dasar untuk meningkatkan kualitas kerja namun di lain pihak masih ada terdapat indikator yang perlu ditingkatkan menjadi lebih tinggi yaitu mengenai salah satunya mengenai indikator memperkecil pengaruh lingkungan fisik, misalnya meredam kebisingan disekitar tempat kerja baik dari luar kantor maupun dari dalam kantor itu sendiri dapat meningkatkan kinerja.

\subsection{Deskripsi Hasil Penelitian Tentang Lingkungan Kerja Non Fisik (X2)}

Berdasarkan hasil jawaban responden melalui penyebaran angket terhadap 74 orang responden, maka peneliti akan menguraikan hasil penelitian per item indikator tentang lingkungan kerja non fisik, berikut ini:

- Lingkungan kerja dipengaruhi oleh semua keadaan yang terjadi yang berkaitan dengan hubungan kerja, baik hubungan dengan atasan, dan bawahan misalnya atasan memberi motivasi kepada bawahan untuk berprestasi. 
Mengenai indikator ini diketahui bahwa responden yang menjawab sangat setuju sebanyak 40 orang $(54,05 \%)$, dan sebanyak 34 orang $(4,95 \%)$ menjawab setuju.

- Hubungan dengan sesama rekan kerja ataupun hubungan dengan bawahan, misalnya dengan menjalin kerjasama yang baik. Mengenai indikator ini diketahui bahwa responden yang menjawab sangat setuju sebanyak 50 orang $(67,57 \%)$, dan sebanyak 24 orang $(32,43 \%)$ menjawab setuju.

- Atasan dan bawahan sama-sama saling menghargai. Mengenai indikator ini diketahui bahwa responden yang menjawab sangat setuju sebanyak 44 orang $(59,46 \%)$, dan sebanyak 30 orang $(40,54 \%)$ menjawab setuju.

- Lingkungan kerja hendaknya diciptakan dalam suasana kekeluargaan, komunikasi yang baik, dan pengendalian diri. Mengenai indikator ini diketahui bahwa responden yang menjawab sangat setuju sebanyak 51 orang $(68,92 \%)$, dan sebanyak 23 orang $(31,08 \%)$ menjawab setuju.

- Lingkungan kerja non fisik merupakan kelompok lingkungan kerja yang tidak bisa diabaikan. Mengenai indikator ini diketahui bahwa responden yang menjawab sangat setuju sebanyak 51 orang $(68,92 \%)$, dan sebanyak 23 orang $(31,08 \%)$ menjawab setuju.

- Pegawai sanggup mengerjakan tugas kedinasan yang diberikan sesuai dengan jadwal yang ditentukan. Mengenai indikator ini diketahui bahwa responden yang menjawab sangat setuju sebanyak 44 orang $(5,46 \%)$, dan sebanyak 30 orang $(40,54 \%)$ menjawab setuju.

- Pegawai menyelesaikan tugas kantor sebelum mengerjakan urusan pribadi. Mengenai indikator ini diketahui bahwa responden yang menjawab sangat setuju sebanyak 44 orang $(59,46 \%)$, dan sebanyak 30 orang $(40,54 \%)$ menjawab setuju.

- Pegawai membantu pekerjaan bidang lain jika ditugaskan atasan pada bidang yang ditempati. Mengenai indikator ini diketahui bahwa responden yang menjawab sangat setuju sebanyak 44 orang $(59,46 \%)$, dan sebanyak 30 orang $(40,54 \%)$ menjawab setuju.

- Pegawai menaati peraturan yang ditetapkan dan bersedia dikenakan sanksi bila melanggar. Mengenai indikator ini diketahui bahwa responden yang menjawab sangat setuju sebanyak 50 orang $(67,57 \%)$, dan sebanyak 24 orang $(32,43 \%)$ menjawab setuju.

- Pegawai bekerja dengan baik dan benar sehingga tujuan organisasi dapat tercapai. Mengenai indikator ini diketahui bahwa responden yang menjawab sangat setuju sebanyak 50 orang $(67,57 \%)$, dan sebanyak 24 orang $(32,43 \%)$ menjawab setuju.

Berdasarkan rekapitulasi hasil jawaban responden untuk lingkungan kerja non fisik diketahui bahwa diperoleh skor kenyataan sebesar 2403 yang diperoleh dari perhitungan berikut ini:

$$
\mathrm{x}=\frac{2403}{10}=240,3
$$

Kemudian jika dipersentasekan adalah sebagai berikut :

$$
\begin{aligned}
\frac{\text { skor rata }- \text { rata }}{\text { skor ideal }} & \times 100 \% \\
& =\frac{240,3}{255} \times 100 \% \\
& =64,94 \%
\end{aligned}
$$

Dengan demikian rata-rata skor untuk lingkungan kerja non fisik sebesar 240,3 yang berada pada posisi tinggi. Apabila ditunjukkan dalam persentase diperoleh angka sebesar $64,94 \%$, yang beraada pada posisi tinggi. Perolehan skor tertinggi diperoleh sebesar 347 yaitu mengenai lingkungan kerja hendaknya diciptakan dalam suasana kekeluargaan, komunikasi yang baik, dan pengendalian diri, sedangkan skor terendah yang diperoleh adalah sebesar 336, yaitu mengenai indikator lingkungan kerja dipengaruhi oleh semua keadaan yang terjadi yang berkaitan dengan hubungan kerja, baik hubungan dengan atasan, dan bawahan misalnya atasan memberi motivasi kepada bawahan untuk berprestasi.

Berdasarkan hasil observasi variabel lingkungan kerja non fisik sudah menyesuaikan dengan ketentuan yang 
berlaku, hal itu dapat dibuktikan dari beberapa indikator yang sudah memiliki hasil yang sangat tinggi diantaranya mengenai lingkungan kerja hendaknya diciptakan dalam suasana kekeluargaan, komunikasi yang baik, dan pengendalian diri namun di lain pihak masih ada beberapa aspek yang perlu ditingkatkan lagi terutama mengenai lingkungan kerja dipengaruhi oleh semua keadaan yang terjadi yang berkaitan dengan hubungan kerja, baik hubungan dengan atasan, dan bawahan misalnya atasan memberi motivasi kepada bawahan untuk berprestasi.

\subsection{Deskripsi Hasil Penelitian Tentang Kinerja Pegawai $(Y)$}

Berdasarkan hasil jawaban responden melalui penyebaran angket terhadap 74 orang responden, maka peneliti akan menguraikan hasil penelitian per item indikator tentang lingkungan kerja non fisik, berikut ini:

- Para pegawai dapat melaksanakan tugasnya dengan cermat dan tepat. Mengenai indikator ini diketahui bahwa responden yang menjawab sangat setuju sebanyak 60 orang $(81,08 \%)$, dan sebanyak 14 orang $(18,92 \%)$ menjawab setuju.

- Para pegawai dapat melaksanakan tugasnya dengan efektif dan efisien. Mengenai indikator ini diketahui bahwa bahwa responden yang menjawab sangat setuju sebanyak 50 orang $(67,57 \%)$, dan sebanyak 24 orang $(32,43 \%)$ menjawab setuju.

- Para pegawai dapat menjelaskan tahapan-tahapan program sesuai dengan petunjuk pelaksanaan. Mengenai indikator ini diketahui bahwa responden yang menjawab sangat setuju sebanyak 44 orang $(59,46 \%)$, dan sebanyak 30 orang $(40,54 \%)$ menjawab setuju.

- Para pegawai bekerja dengan sungguhsungguh sehingga terhindar dari kesalahan-kesalahan dalam pelaksanaan tugasnya. Mengenai indikator ini diketahui bahwa responden yang menjawab sangat setuju sebanyak 51 orang $(68,92 \%)$, dan sebanyak 23 orang $(31,08 \%)$ menjawab setuju.
- Para pegawai dapat mensosialisasikan program dengan cepat pada sejumlah penerima bantuan yang menjadi sasaran program. Mengenai indikator ini diketahui bahwa responden yang menjawab sangat setuju sebanyak 51 orang $(68,92 \%)$, dan sebanyak 23 orang $(31,08 \%)$ menjawab setuju.

- Para pegawai menampung semua keluhan. Mengenai indikator ini diketahui bahwa responden yang menjawab sangat setuju sebanyak 44 orang $(59,46 \%)$, dan sebanyak 30 orang $(40,54 \%)$ menjawab setuju.

- Para pegawai melakukan kunjungan guna pengawasan program sesuai dengan jadwal yang telah ditetapkan. Mengenai indikator ini diketahui bahwa responden yang menjawab sangat setuju sebanyak 64 orang $(86,47 \%)$, dan sebanyak 10 orang $(13,53 \%)$ menjawab setuju.

- Para pegawai dapat menyelesaikan dan menyampaikan laporan pelaksanaan sesuai dengan target waktu yang ditetapkan. Mengenai indikator ini diketahui bahwa responden yang menjawab sangat setuju sebanyak 44 orang $(59,46 \%)$, dan sebanyak 30 orang $(40,54 \%)$ menjawab setuju.

- Para pegawai paham akan adanya aturan dan batasan-batasan yang telah ditetapkan. Mengenai indikator ini diketahui bahwa responden yang menjawab sangat setuju sebanyak 50 orang $(67,57 \%)$, dan sebanyak 24 orang $(32,43 \%)$ menjawab setuju.

- Pimpinan dan bawahan bekerjasama dengan baik dalam melaksanakan tugas pokok dan fungsi yang telah ditetapkan. Mengenai indikator ini diketahui bahwa responden yang menjawab sangat setuju sebanyak 50 orang $(67,57 \%)$, dan sebanyak 24 orang $(32,43 \%)$ menjawab setuju.

Selanjutnya berdasarkan rekapitulasi hasil jawaban responden untuk kinerja pegawai diketahui bahwa diperoleh skor kenyataan sebesar 2450 yang diperoleh dari perhitungan berikut ini:

$$
x=\frac{2450}{10}=245
$$


adalah sebagai berikut:

Kemudian jika dipersentasekan

$$
\begin{aligned}
\frac{\text { skor rata }- \text { rata }}{\text { skor ideal }} & \times 100 \% \\
& =\frac{245}{370} \times 100 \% \\
& =66,21 \%
\end{aligned}
$$

Dengan demikian rata-rata skor untuk kinerja pegawai sebesar 245 yang berada pada posisi tinggi. Apabila ditunjukkan dalam persentase diperoleh angka sebesar $66,21 \%$, yang berada pada posisi tinggi. Perolehan skor tertinggi diperoleh sebesar 360 yaitu salah satunya mengenai indikator pegawai melakukan kunjungan guna pengawasan program sesuai dengan jadwal yang telah ditetapkan, sedangkan skor terendah yang diperoleh adalah sebesar 340, salah satunya mengenai indikator pegawai menjelaskan tahapan-tahapan program sesuai dengan petunjuk pelaksanaan.

Berdasarkan hasil observasi variabel kinerja pegawai sudah menyesuaikan dengan ketentuan yang berlaku, hal itu dapat dibuktikan antara lain pegawai melakukan kunjungan guna pengawasan program sesuai dengan jadwal yang telah ditetapkan, namun di lain pihak masih ada beberapa aspek yang perlu ditingkatkan lagi terutama dalam hal pegawai menjelaskan tahapantahapan program sesuai dengan petunjuk pelaksanaan.

\section{PEMBAHASAN}

\subsection{Lingkungan Kerja Fisik Terhadap Kinerja Pegawai Pada Sekretariat Daerah Kabupaten Pangandaran}

Ketika melakukan pekerjaan maka karyawan atau pegawai sebagai manusia tidak dapat dipisahkan dari berbagai keadaan disekitar tempat mereka bekerja, yaitu lingkungan kerja. Selama melakukan pekerjaan, setiap pegawai akan berinteraksi dengan berbagai kondisi yang terdapat dalam lingkungan kerja.

Untuk dapat memperkecil pengaruh lingkungan fisik terhadap karyawan, maka langkah pertama adalah harus mempelajari manusia, baik mengenai fisik dan tingkah lakunya maupun mengenai fisiknya, kemudian digunakan sebagai dasar memikirkan lingkungan fisik yang sesuai.

Menurut Sedarmayanti (2011:21), "Lingkungan kerja fisik adalah semua keadaan berbentuk fisik yang terdapat di sekitar tempat kerja yang dapat mempengaruhi karyawan baik secara langsung maupun scara tidak langsung.

Lingkungan kerja fisik menurut Sarwono (2015:86) dapat dibagi dalam dua kategori, yakni:

1. Lingkungan yang langsung berhubungan dengan karyawan (Seperti: pusat kerja, kursi, meja dan sebagainya)

2. Lingkungan perantara atau lingkungan umum dapat juga disebut lingkungan kerja yang mempengaruhi kondisi manusia, misalnya :temperatur, kelembaban, sirkulasi udara, pencahayaan, kebisingan, getaran mekanis, bau tidak sedap, warna, dan lain-lain.

Faktor lain yang mempengaruhi lingkungan kerja fisik adalah rancangan ruang kerja. Rancangan ruang kerja yang baik dapat menimbulkan kenyamanan bagi pegawai di tempat kerjanya. Faktor-faktor dari rancangan ruang kerja tersebut menurut Robbins (2012:318) terdiri atas: “a) Ukuran ruang kerja, b) Pengaturan ruang kerja, c) Privasi”.

Berbagai hal yang menyangkut lingkungan kerja fisik dapat memberikan dampak positif serta signifikan pada kinerja pegawai apabila mengikuti indikator-indikator yang menjadi pendukung lingkungan kerja fisik. Indikator-indikator yang menjadi pendukung lingkungan kerja fisik mengacu pada pendapat (Sedarmayanti, 2011:21) sebagai berikut:

a. Semua keadaan berbentuk fisik yang terdapat disekitar tempat kerja yang dapat mempengaruhi pegawai baik secara langsung maupun tidak langsung

b. Lingkungan kerja yang langsung berhubungan dengan pegawai seperti pusat kerja, kursi, meja, dan sebagainya.

c. Lingkungan perantara atau lingkungan umum dapat juga disebut 


lingkungan kerja yang
mempengaruhi kondisi manusia
misalnya temparatur, kelembaban,
sirkulasi udara, pencahayaan,
kebisingan, getaran mekanik, bau
tidak sedap, warna dan lain-lain.

d. Memperkecil penguruh lingkungan fisik terhadap karyawan dengan cara mempelajari manusia, baik mengenal fisik dan tingkah lakunya, kemudian digunakan sebagai dasar memikirkan lingkungan fisik yang sesuai.

Dari uraian di atas dapat diketahui bahwa indikator-indikator lingkungan kerja fisik di atas telah diterapkan di Sekretariat Daerah Kabupaten Pangandaran, walaupun pada kenyataannya tidak semua indikator tersebut mempunyai nilai yang sangat tinggi, karena sebagaimana hasil penelitian mengenai indikator lingkungan kerja fisik, salah satu indikator terendah adalah mengenai memperkecil penguruh lingkungan fisik, misalnya meredam kebisingan disekitar tempat kerja baik dari luar kantor maupun dari dalam kantor itu sendiri dapat meningkatkan kinerja.

Dengan demikian dapat diketahui bahwa semakin positif nilai lingkungan kerja fisik tersebut dilaksanakan oleh setiap pegawai pada Sekretariat Daerah Kabupaten Pangandaran, maka akan semakin berdampak baik pada kinerja pegawai di Sekretariat Daerah Kabupaten Pangandaran.

\subsection{Lingkungan Kerja Non Fisik Terhadap Kinerja Pegawai Pada Sekretariat Daerah Kabupaten Pangandaran}

Manusia akan mampu melaksanakan kegiatannya dengan baik, sehingga dicapai suatu hasil yang optimal, apabila diantaranya ditunjang oleh suatu kondisi lingkungan yang sesuai. Suatu kondisi lingkungan dikatakan baik atau sesuai apabila manusia dapat melaksanakan kegiatannya secara optimal, sehat, aman, dan nyaman. Ketidaksesuaian lingkungan kerja dapat dilihat akibatnya dalam jangka waktu yang lama. Lebih jauh lagi, Keadaan lingkungan yang kurang baik dapat menuntut tenaga dan waktu yang lebih banyak dan tidak mendukung diperolehnya rancangan sistem kerja yang efisien. Banyak faktor yang mempengaruhi terbentuknya suatu kondisi lingkungan kerja. (silviasigit.blogspot.co.id, 2010).

Menurut Sedarmayanti (2011:31), "Lingkungan kerja non fisik adalah semua keadaan yang terjadi yang berkaitan dengan hubungan kerja, baik hubungan dengan atasan maupun hubungan sesama rekan kerja, ataupun hubungan dengan bawahan".

Lingkungan non fisik ini juga merupakan kelompok lingkungan kerja yang tidak bisa diabaikan. Menurut Nitisemito (2010:171173) Perusahaan hendaknya dapat mencerminkan kondisi yang mendukung kerja sama antara tingkat atasan, bawahan maupun yang memiliki status jabatan yang sama di perusahaan. Kondisi yang hendaknya diciptakan adalah suasana kekeluargaan, komunikasi yang baik, dan pengendalian diri.

Dalam lingkungan kerja non fisik maka membina hubungan yang baik antara sesama rekan kerja, bawahan maupun atasan perlu dilakukan karena saling membutuhkan dan hal tersebut menjadi peran paling penting. Hal tersebut sangat berdasar karena hubungan kerja yang terbentuk sangat mempengaruhi psikologis karyawan.

Mengacu pada uraian di atas menurut Mangkunegara (2010:9), sebagai bagian dari lingkungan kerja non fisik maka untuk menciptakan hubungan-hubungan yang harmonis dan efektif, pimpinan perlu:

1) meluangkan waktu untuk mempelajari aspirasi-aspirasi emosi pegawai dan bagaimana mereka berhubungan dengan tim kerja dan 2) menciptakan suasana yang meningkatkan kreativitas. Pengelolaan hubungan kerja dan pengendalian hubungan kerja dan pengendalian emosional di tempat kerja itu sangat perlu untuk diperhatikan karena akan memberikan dampak terhadap prestasi kerja pegawai. Hal ini disebabkan karena manusia itu bekerja bukan sebagai mesin. Manusia mempunyai perasaan untuk dihargai dan bukan bekerja untuk uang saja.

Berbagai hal yang menyangkut lingkungan kerja non fisik dapat memberikan dampak positif serta signifikan pada kinerja pegawai apabila mengikuti indikator-indikator yang 
menjadi pendukung lingkungan kerja non fisik. Indikator-indikator yang menjadi pendukung lingkungan kerja non fisik antara lain mengacu pada pendapat (Sedarmayanti, 2011:21) sebagai berikut:

a. Semua keadaan yang terjadi yang berkaitan dengan hubungan kerja, baik hubungan dengan atasan, maupun hubungan dengan sesama rekan kerja ataupun hubungan dengan bawahan.

b. Perusahaan hendaknya dapat mencerminkan kondisi yang mendukung kerja sama antar tingkat atasan, bawahan maupun yang memiliki status yang sama.

c. Lingkungan kerja hendaknya diciptakan dalam suasana kekeluargaan, komunikasi yang baik, dan pengendalian diri

d. Lingkungan kerja non fisik merupakan kelompok lingkungan kerja yang tidak bisa diabaikan.

Dari uraian di atas dapat diketahui bahwa indikator-indikator lingkungan kerja non fisik di atas telah diterapkan di Sekretariat Daerah Kabupaten Pangandaran, walaupun pada kenyataannya tidak semua indikator tersebut mempunyai nilai yang sangat tinggi, karena sebagaimana hasil penelitian mengenai indikator lingkungan kerja non fisik maka indikator lingkungan kerja dipengaruhi oleh semua keadaan yang terjadi yang berkaitan dengan hubungan kerja, baik hubungan dengan atasan, dan bawahan misalnya atasan memberi motivasi kepada bawahan untuk berprestasi memiliki nilai terendah.

Dengan demikian dapat diketahui bahwa semakin positif nilai lingkungan kerja non fisik tersebut dilaksanakan oleh setiap pegawai pada Sekretariat Daerah Kabupaten Pangandaran, maka akan semakin berdampak baik pada kinerja pegawai di Sekretariat Daerah Kabupaten Pangandaran.

\subsection{Pengaruh Lingkungan Kerja Fisik dan Lingkungan Kerja Non Fisik Terhadap Kinerja Pegawai Pada Sekretariat Daerah Kabupaten Pangandaran}

Kinerja adalah sebuah keluaran dari suatu proses baik secara kualitas maupun kuantitas yang dicapai oleh seorang pegawai/karyawan dari hasil perpaduan atau interaksi antara kemampuan, motivasi dan kesempatan dalam melaksanakan tugas sesuai dengan tanggung jawab yang diberikannya.Tinggi rendahnya kinerja pegawai tergantung kepada keyakinan mereka terhadap kepemimpinan, sasaran, dan pekerjaan mereka sendiri.

Mengenai kinerja pegawai, maka kinerja itu harus dikelola, terutama untuk mencapai produktivitas dan efektivitas dalam rangka merancang bangun kesuksesan, baik secara individu maupun organisasi. Dengan demikian, manajemen kinerja merupakan suatu pendekatan untuk mencapai visi, misi, tujuan, dan target yang akan dicapai melalui kerja tim. Tim yang memiliki kinerja baik, maka anggotanya akan menetapkan standar kualitas target, mencapai target, memahami perbedaan, saling menghormati, berimbang dalam peran, berorientasi pada klien, mengevaluasi kinerja, dan bekerja sama.

Hal di atas sesuai dengan pendapat yang dikemukakan oleh Samsudin (2015:159) yang menyebutkan bahwa: "Kinerja adalah tingkat pelaksanaan tugas yang dapat dicapai seseorang, unit atau divisi dengan menggunakan kemampuan yang ada dan batasan-batasan yang telah ditetapkan untuk mencapai tujuan organisasi/perusahaan".

Dapat disimpulkan bahwa kinerja adalah sifat dan karakteristik suatu pekerjaan yang dinyatakan sebagai catatan kerja seseorang, dengan kriteria pengembangan diri, kerja tim, komunikasi, jumlah produk yang dihasilkan, dan keputusan yang dibuat, kecelakaan kerja, absen tanpa izin, kesalahan dalam kurun waktu. Kriteria kinerja setiap orang didasarkan kepada tugas dan tanggung jawab keseharian yang ditargetkan kepadanya. Kinerja berfungsi sebagai alat untuk memberi informasi bagi pekerja dan atasannya mengenai bagaimana seseorang telah melakukan pekerjaan, dan kinerja adalah fungsi dari interaksi antara kemampuan dan karakter kepribadian.

Berbagai hal yang menyangkut kinerja pegawai dapat memberikan dampak positif serta signifikan pada lingkungan kerja fisik dan lingkungan kerja non fisik apabila mengikuti indikator-indikator yang menjadi pendukung kinerja pegawai. Indikatorindikator yang menjadi pendukung kinerja 
pegawai yang mengacu pada pendapat Mangkunegara (2003) yaitu:

a) Para pegawai dapat melaksanakan tugasnya dengan cermat dan tepat

b) Para pegawai dapat melaksanakan tugasnya dengan efektif dan efisien

c) Para pegawai dapat menjelaskan tahapan-tahapan program sesuai dengan petunjuk pelaksanaan

d) Para pegawai bekerja dengan sungguh-sungguh sehingga terhindar dari kesalahan-kesalahan dalam pelaksanaan tugasnya

e) Para pegawai dapat mensosialisasikan program dengan cepat pada sejumlah penerima bantuan yang menjadi sasaran program

f) Para pegawai menampung semua keluhan

g) Para pegawai melakukan kunjungan guna pengawasan program sesuai dengan jadwal yang telah ditetapkan

h) Para pegawai dapat menyelesaikan dan menyampaikan laporan pelaksanaan sesuai dengan target waktu yang ditetapkan

Dari uraian di atas dapat diketahui bahwa indikator-indikator kinerja pegawai di atas telah diterapkan di Sekretariat Daerah Kabupaten Pangandaran, walaupun pada kenyataannya tidak semua indikator tersebut mempunyai nilai yang sangat tinggi, karena sebagaimana hasil penelitian diketahui bahwa indikator pegawai menjelaskan tahapan-tahapan program sesuai dengan petunjuk pelaksanaan mempunyai nilai terendah.

\section{SIMPULAN}

Berdasarkan hasil analisis diperoleh kesimpulan bahwa terdapat pengaruh yang positif dan signifikan antara variabel lingkungan kerja fisik (X1) dan lingkungan kerja non fisik (X2) dengan kinerja pegawai (Y). Hasil analisis menunjukkan bahwa efektivitas kerja dipengaruhi oleh koordinasi dan komunikasi sebesar koefisien korelasi yang ditemukan sebesar 0,919. Hal tersebut menujukkan bahwa terdapat pengaruh yang sangat tinggi dari
X1 dan X2 terhadap Y. Untuk menyatakan besar atau kecilnya suatu kontribusi/sumbangan dari variabel $\mathrm{X} 1$ dan $\mathrm{X} 2$ terhadap variabel $\mathrm{Y}$, dapat dilihat dari hasil perhitungan koefisien determinasi sebesar 0,844. Nilai ini menunjukkan bahwa lingkungan kerja fisik (X1) serta lingkungan kerja non fisik (X2) berpengaruh secara signifikan terhadap kinerja pegawai (Y) sebesar 84,4\%, sedangkan sisanya sebesar $15,6 \%$ dipengaruhi oleh variabel lain di luar variabel yang diteliti.

\section{DAFTAR PUSTAKA}

Alwi, Syafaruddin, 2011. Manajemen Sumber Daya Manusia Strategi Keunggulan. Kompetitif, BPFE, Yogyakarta.

Arikunto, Suharsimi. 2000. Prosedur Penelitian Suatu Pendekatan Praktek. Jakarta. PT. Rineka Cipta.

Barker, Chris. 2010. Cultural Studies, Theory and Practice. London: Sage. Publications.

Bernardin, W Taylor III and Rusell, Roberta S. 2013. Operation Management : Focusing On Quality Competivitions, Edition 2, PrenticeHall International Inc, Uppersadle River, New Jersey.

Bambang, Hartono Sugih. 2010. Pemasaran dan Produktivitas dalam Manajemen. Jakarta: Sinar Grafika.

Casio, Wayne F. 2012. Managing Human Resources: Productivity, Quality of Work Life, Profit. Singapore: McGraw-Hill International Editors.

Creswell, John. 2015. Desain Penelitian. Jakarta: KIK Press

Donnelly, James H., Gibson, James L., and Ivancevich, John, 2014, Fundamental of Management. Texas: Business Publication.

Dwiyanto, Agus. 2016. Penilaian Kinerja Organisasi Pelayanan Publik. Yogyakarta : Gajahmada University Press.

Dunn, William N. 2010. Public policy Analysis: An Introduction. Second Edition. Prentice-Hall Inc and Simon and Schuster Company, Englewood Cliffs, New Jersey. USA. 
Griffin, Ricky W., 2014, Management. Boston: Houghton Miffin.

Gomes, Faustino Cardozo. 2003. Manajemen Sumber Daya Manusia. Yogyakarta: CV Andi Offset.

Hasibuan, Malayu SP. 2012. Manajemen Dasar, Pengertian dan Masalah. Jakarta : Gunung Agung.

Hunt and Osborn. 2012. Managing Organizational Behaviour, New York . Prentice Hill.

Iskandar. 2014. Metodologi Penelitian Kualitatif. Jakarta: Gaung Persada Press.

Ishak, Arep dan Tanjung, Henry. 2013. Manajemen Motivasi, Jakarta: Gramedia.

Jones, Pam. 2012. Buku Pintar Manajemen Kinerja. Terjemahan Anthony R. Indra. Jakarta : Metalexia Publishing \& PT Qreator Tata Qarakter.

Jacobus, Tarigan. 2011. Etika Bisnis: Dasar dan Aplikasinya, Jakarta: Komisi Kerasulan Awam KWI dan Grasindo.

Mangkunegara. 2003. Manajemen Sumber Daya Manusia Perusahaan. Bandung : PT. Remaja Rosdakarya.

Manullang, M., dan Marihot AMH Menulang. 2014. Manajemen Personalia. Yogyakarta: Gadjah Mada University Press.

Mardiana. 2015. Manajemen Produksi. Jakarta:IPWI.

Nitisemito, Alex S. 2010. Manajemen Personalia. Jakarta: Ghalia Indonesia.

Pasolong, Harbani. 2014. Kepemimpinan Birokrasi. CV. Alfabeta : Bandung.

Prawirosentono, Suryadi. 2011. Manajemen SDM Kebijakan Kinerja Karyawan Kiat. Membangun Organisasi Kompetitif Menjelang Perdagangan Bebas Dunia. Yogyakarta, BPFE.

Robbins, Stephen P. 2012. Organizational Behavior 10th edition, USA: Prentice-Hall, International Inc.

Rivai, Veitzhal. 2005. Kepemimpinan Dan Perilaku Organisasi, Jakarta: PT. Raja Grafindo Persada.

Sugiyono, 2010. Metode Penelitian. Bandung : Alfabeta.
Schermerhorn, John R. 2012. Manajemen, edisi kelima, Andi Yogyakarta.

Samsudin, Sadili. 2015. Manajemen Sumber Daya Manusia. Bandung: Penerbit. Pustaka Setia.

Siagian, P Sondang. 2006. Fungsi-fungsi Manajemen. Jakarta. Penerbit Bumi Aksara.

Sarwono, Prawirohardjo. 2015. Landasan Psikologi Proses Pendidikan. Jakarta: Bumi Aksara.

Sedarmayanti. 2011. Manajemen Sumber Daya Manusia. Yogyakarta: STIE YKPN.

Simamora, Henry. 2014. Manajemen Sumber Daya Manusia, Reformasi Birokrasi dan Manajemen Pegawai Negeri Sipil. Bandung; Mandar Maju.

Stolovitch, Harold D., and Keeps, Erica J., 2012, Handbook of Human Performance Technology A Comprehensive Guide for Analysis and Solving Performance Problem in Organizations. San Francisco: Jersey-Bass Publisher.

Sumanto. 2015. Manajemen Karyawan, Yogyakarta: Amus.

Widodo, 2014. Membangun Birokrasi Berbasis Kinerja. Bayumedia Publishing : Jakarta.

Winardi, 2010, Manajer dan Manajemen. Bandung: Citra Aditya Bakti.

Wood et al, Jack. 2011. Organizational Behaviour: A Global Perspective. Australia : John Wiley and Son.

Zainun, Buchari. 2010. Manajemen dan Motivasi. Jakarta : Balai Aksara. 
